\title{
HOSPITALITAS SEBAGAI TANGGUNG JAWAB PEMUDA-PEMUDI KRISTEN DI TENGAH PANDEMI COVID-19
}

\author{
LORENSIA PATODINGAN \\ INSTITUT AGAMA KRISTEN NEGERI (IAKN) TORAJA \\ lorensiapatodingan@gmail.com
}

\begin{abstract}
Abstrak :
Pada akhir tahun 2019 dunia di kejutkan oleh pandemi yang di sebabkan oleh Virus Corona. Covid19 menimbulkan kekhwatiran dan ketakutan bagi dunia karena penyebarannya yang sangat cepat dan mematikan. Negara indonesia juga termasuk salah satu Negara yang terimbas oleh Virus Corona pada Tanggal 19 Maret 2020, ada 309 kasus positif dan semakin bertambah. Masyarakat Indonesia menerima anjuran dari pemerintah namun terdapat beberapa reaksi seperti panic buying, terhadap tenaga kesehatan yang terpapar covid-19. Tulisan ini bertujuan untuk merumuskan model sikap etis Hospitalitas Kristen di tengah pandemic covid-19. Dengan penelitian ini ada harapan bagi pemuda kristen Indonesia untuk menatap dengan serius kasus yang di alami Negara saat ini dan tanggung jawab mereka baik dalam pelayanan gereja maupun masyarakat.
\end{abstract}

Kata kunci: Hospilatitas, Tanggung jawab pemuda-pemudi, Pandemi Covid-19

\begin{abstract}
Abstrack :
At the of 2019 the world wa shockedby a pandemic caused by the Corona Virus. Covid-19 cause concern adn fear for the world because of its very fast and deadly spread. Indonesia is also one of the number is increasing. The people of Indonesia accepted the advice from the goverment, but there were some reactions, such as panic buying, against halth workers who were exposed to COVID-19. This paper aims to formulate a model for the ethical attitude of Christian Hospitality in the midst of the COVID-19 pandemic. With this reseach, there is hope for Indonesian Christian youth to take seriously the cases currently being experienced by the State and their reponsibilities both in church and community service
\end{abstract}

Key words : Hospitality, the responsibility of young people, the COVID-19 pandemic 


\section{PENDAHULUAN}

1Pandemi Covid-19 telah menjadi problematika global saat ini. Penyebaran Virus tersebut telah menyebabkan berbagai krisis, baik di bidang kesehatan, ekonomi, politik maupun keagamaan. Segala upaya yang di lakukan oleh pemerintah di dunia sehingga dapat dilakukan dengan mencegah penyebaran covid-19 dengan berbagai cara dan kebijakan, peraturan protocol kesehatan dan penerapan secara teknis. Setiap pemerintah dan setiap warna Negara berusaha seoptimal mungkin untuk melaksanakan sikap dan tindakan sosial distance (jaga jarak sosial, pertemuan), menggunakan masker penutup hidung dan mulut yang baik dan benar, cara mencuci tangan yang benar serta himbauan dan perintah untuk tetap tinggal dirumah saja. Hal ini di lakukan Negara sejak pandemic covid-19 semakin meningkat.

Tempat dan kondisi ibadah tidak menjadi ukuran atau standar bagi pemuda di dalam pelaksanaan ibadah kepada Allah Tritunggal. Karena hakekat ibadah sesungguhnya di dalam persekutuan orang percaya selalu berpusat pada Allah tritunggal dan kebenaran firman Tuhan sebagai arahnya. Molmant menulis dalam Bukunya "Theology of hope", Ia menyebutkan bahwa betapa pentingnya Gereja dalam memperlakukan yang seperti: "Gereja tidak hadir dalam dirinya sendiri, melainkan selalu ada untuk orang lain". Ini merupakan Gereja Allah yang adalah sebuah Gereja yang dapat menghadirkan Allah di tengah-tengah dunia ini" (Molmann, 1997, Hal 327). Dari pernyataan tersebut pemuda seakan terasingkan khususnya dalam ibadah persekutuan Pemuda Gereja Toraja. ${ }^{2}$

Dengan virtual atau Online, sebagai implementasi peraturan pemerintah dalam memutus mata rantai pandemic covid-19. Perubahan proses pembelajaran yang mendadak menjadi pembelajaran virtual. Untuk menjawab permasalahan tersebut di butuhkan pendidikan karakter dengan karasteristik nilai-nilai Kristen (mengetahui nilai kebaikan, dan memberikan dampak yang baik bagi lingkungan di sekitarnya), terpatri dalam diri dan terwujud dalam perilaku. Di antaranya karakter integritas meliputi sikap tanggung jawab sebagi pemuda warga Negara Indonesia, aktif terlibat dalam kehidupan sosial melalui konsintensi dan tindakan, perkataan yang berdasarkan kebenaran. Menurut worsono tanggung jawab pemuda sebagai warga Negara yang baik, meliputi tanggung jawab terhadap diri sendiri, kelurga, lingkungan dan Tuhan Yang Maha Esa. Terkait dengan sikap

\footnotetext{
${ }^{1}$ Daniel Fajar Panuntun and Eunike Paramita, "Hospitalitas Kristen Dan Tantangannya Di Tengah Pandemi Covid19," Harmoni 19, no. 1 (2020)

${ }^{2}$ Andar Ismail, ajarlah mereka melakukan, (Jakarta:BPK Gunung Mulia, 2012), Hal 140
} 
tanggung jawab pemuda terhadap lingkungan, masyarakat, dan Gereja lebih di tekankan untuk saling peduli dalam lingkup mereka. ${ }^{3}$

\section{TUJUAN DAN MANFAAT}

Tujuan penelitian ini yaitu untuk memberikan pemahaman kepada Generasi muda bahwa tugas dan tanggung jawab mereka sangat di butuhkan dalam lingkungan sekitar, baik dalam lingkup keluarga, Gereja dan Masyarakat. Manfaatnya yaitu dapat mengembakan suatu ide dan kreativitas terhadap lingkungan sekitar dan memanfaatkan media yang ada dalam mengembangkan spritualitas pemuda Kristen di tengah pandemic covid-19.

\section{PEMBAHASAN}

Persoalan utama yang menjadi pembahasan dalam kajian ini adalah bagaimana sikap dan tanggung jawab pemuda pemudi Kristen di tengah pandemi Covid-19. Hal ini disebabkan dilematika yang terjadi akibat kegamangan kebijakan protokol kesehatan yang dimaknai oleh masyarakat secara etis situasional, yaitu bahwa masyarakat melakukan tindakan yang benar sesuai konteks, namun menurut persepsi masing-masing. Hal ini terlihat dari berbagai aksi seperti panic buying dan penolakan pemakaman warga yang positif Covid-19. Tentunya hal tersebut akan mengkikis rasa hospitalitas yang harus dimiliki umat manusia. Malangnya, hospitalitas tersebut pada masa ini juga dapat menjadi momok, karena dapat menjadi suatu sarana penyebaran pandemik semakin meluas. Tulisan ini akan mengkaji pembahasan masalah yang dilematik ini sehingga dapat ditemukan suatu tindakan etis berdasarkan hospitalitas Kristen yang dapat dikerjakan oleh masyarakat demi menyikapi hilangnya rasa keramahtamahan/hospitalitas di tengah wabah. ${ }^{4}$

\section{CORONAVIRUS}

Coronavirus Disease 2019 (COVID-19) adalah penyakit menular yang disebabkan oleh Severe Acute Respiratory Syndrome Coronavirus 2 (SARSCoV-2). SARS-CoV-2 merupakan coronavirus jenis baru yang belum pernah diidentifikasi sebelumnya pada manusia. Ada setidaknya dua jenis coronavirus yang diketahui menyebabkan penyakit yang dapat menimbulkan gejala berat seperti Middle East Respiratory Syndrome (MERS) dan Severe Acute Respiratory Syndrome (SARS). Tanda dan gejala umum infeksi COVID-19 antara lain gejala gangguan pernapasan akut seperti demam, batuk dan sesak napas. Masa inkubasi rata-rata 5-6 hari dengan masa inkubasi terpanjang 14 hari. Pada kasus

\footnotetext{
${ }^{3}$ Dr. Dra. Badruli Martati, S.H., MA., M.Pd, sikap tanggung jawab pemuda di masa pandemic covid-19 ${ }^{4}$ Daniel Fajar Panuntun and Eunike Paramita, "Hospitalitas Kristen Dan Tantangannya Di Tengah Pandemi Covid19," Harmoni 19,hlm 72
} 
COVID-19 yang berat dapat menyebabkan pneumonia, sindrom pernapasan akut, gagal ginjal, dan bahkan kematian. ${ }^{5}$

Menurut Bernhard Kieser, iman gereja baru memperoleh wujud dan menjadi kenyataan jika meninggalkan ruang Gereja dan menggemakan jawaban manusia akan panggilan Allah justru berhadapan dengan tantangan hidup sehari-hari. Jawaban iman berhadapan dengan soal-soal duniawi hanya dapat merupakan tanggapan dan tanggung jawab bagi generasi muda. Dengan ini Gereja memberikan tanggung jawab kepada generasi mudah untuk ikut membantu dalam penanggulangan wabah covid-19 yang membuat masyarakat setempat menjadi kawatir bahkan ketakutan. 6

\section{TANGGUNG JAWAB PEMUDAPEMUDIKRISTEN DI TENGAH PANDEMI COVID-19}

Dalam sambutannya, Mendikbudristek menyampaikan bahwa pelajar menjadi kelompok usia yang mengalami dampak terbesar akibat pandemi Covid-19. Di tengah usaha giatnya dalam menggapai mimpi, para generasi muda tersebut harus menghadapi tantangan yang sangat besar dan tidak bisa dihindari. Namun, tidak sedikit pula pelajar dan mahasiswa yang turut meluangkan waktu, tenaga, dan pikirannya untuk membantu sesama.

Pemuda kristen membawa implikasi dan perubahan yang cukup besar dalam penanganan Covid-19. "Salah satunya sebagai role model untuk agent of change di mana anak muda ini ikut peran serta dalam melakukan kegiatan-kegiatan yang berhubungan dengan 3M (memakai masker, mencuci tangan, dan menjaga jarak)," para pemuda ini juga bisa ikut berperan dalam proses-proses transformasi kesehatan di masa pandemi misalnya melakukan penggalangan dana untuk memperoleh akses yang lebih baik.

Generasi muda hendaknya memperlihatkan kerukunan mereka baik dalam lingkup gereja maupun masyarakat sekitar. Pemuda harus menjadi teladan bagi gereja untuk membentuk sebuah ketertiban agar tidak terjadi konflik di tengah pandemic covid-19. Pemuda harus memperhatikan sesama mereka tanpa melihat latar belakang mereka apa tetapi generasi mudah harus memperlihatkan kerukunan terhadap masyarakat dan memberikan perhatian kepada meraka yang terkena dampak covid-19 dengan tetap mematuhi protocol kesehatan dari pemerintah. Sebagai pemuda Kristen hendaknya melihat di budaya mana mereka berada. Karena salah satu yang mempengaruhi pemuda saat ini adalah budaya. Gereja juga harus berpikir kritis mengenai budaya dan bagaimana tanggung jawab pemuda saat ini di tengah pandemic covid-19 yang di alami Negaranegara pada saat ini. Mereka harus memperhatikan berbagai hal dalam melakukan tugas dan

\footnotetext{
${ }^{5}$ pedoman pencegahan dan pengendalian coronavirus di sease (Covid-19)

${ }^{6}$ Bernhard Kieser, Op.Cit., hal.85
} 
tanggung jawab mereka sebagai pemuda Kristen yang memiliki kreativitas dan tanggung jawab mereka. ${ }^{7}$

\section{KESIMPULAN}

Dari penelitian ini dapat di simpulkan bahwa pemuda kristen sangatlah penting dalam membantu pencegahan covid-19. Pemuda kristen membawa implikasi dan perubahan yang cukup besar dalam penanganan Covid-19. "Salah satunya sebagai role model untuk agent of change di mana anak muda ini ikut peran penting serta dalam melakukan kegiatan-kegiatan yang berhubungan dengan 3M (memakai masker, mencuci tangan, dan menjaga jarak)," para pemuda ini juga bisa ikut berperan dalam proses-proses transformasi kesehatan di masa pandemi misalnya melakukan penggalangan dana untuk memperoleh akses yang lebih baik. Mereka harus memperhatikan berbagai hal dalam melakukan tugas dan tanggung jawab mereka sebagai pemuda Kristen yang memiliki kreativitas dan tanggung jawab mereka.

\section{SARAN}

Saran saya terhadap tanggung jawab pemuda-pemudi kristen di tengah pandemi Covid-19 adalah tetap menjadi pemuda-pemudi yang penuh tanggung jawab dan harus selalu membantu sesama. Sebagai pemuda-pemudi kristen harus membawa perubahan besar dalam penanganan Covid-19. Generasi muda hendaknya memperlihatkan kerukunan mereka baik dalam lingkup gereja maupun masyarakat sekitar. Pemuda harus menjadi teladan bagi gereja untuk membentuk sebuah ketertiban agar tidak terjadi konflik di tengah pandemic covid-19. Pemuda harus memperhatikan sesama mereka tanpa melihat latar belakang mereka apa tetapi generasi mudah harus memperlihatkan kerukunan terhadap masyarakat dan memberikan perhatian kepada meraka yang terkena dampak covid-19 dengan tetap mematuhi protocol kesehatan dari pemerintah. Sebagai pemuda Kristen hendaknya melihat di budaya mana mereka berada.

\footnotetext{
${ }^{7}$ Yohanes K. Susanta, “Hospitalitas Sebagai Upaya Mencegah Kekerasan Dalam Memelihara Kerukunan Dalam Relasi Islam - Kristen Di Indonesia,"
} 


\section{REFERENSI}

Panuntun, Daniel Fajar, Eunike Paramita, "Hospitalitas Kristen dan tantangannya di Tengah Pandemi

Covid-19" Jurnal Multikultural dan Multi Religius 19, no.1 (Oktober 2020)

Ismail Andar, Ajarlah Mereka Melakukan. Jakarta BPK Gunung Mulia, 2012

Martati Badruli, "Sikap Tanggung Jawab Pemuda di masa Pandemi covid-19”

Kisser, Bemhard. Op cit

Susanta, Yohanse K, "Hospitalitas sebagao upaya mencegah kekerasan dalam memelihara Kerukunan dalam relasi Islam-Kristen Di Indonesia" 